\title{
Levels and Risk Assessment of Polychlorinated Biphenyls (PCBS) in Soils from Informal E-Waste Recycling Sites in Cameroun
}

\author{
Romaric E. Ouabo 1*, Abimbola Y. Sangodoyin ${ }^{2}$, Mary B. Ogundiran ${ }^{3}$, Babafemi A. Babalola ${ }^{3}$ \\ ${ }^{1}$ Life and Earth Sciences Institute, Environmental Management, Pan African University, University of Ibadan, NIGERIA \\ 2 Agricultural and Environmental Engineering Department, Faculty of Technology, University of Ibadan, NIGERIA \\ ${ }^{3}$ Department of Chemistry, Faculty of Sciences, University of Ibadan, NIGERIA
}

*Corresponding Author: eouabo0126@stu.ui.edu.ng

Citation: Ouabo, R. E., Sangodoyin, A. Y., Ogundiran, M. B. and Babalola, B. A. (2018). Levels and Risk Assessment of Polychlorinated Biphenyls (PCBS) in Soils from Informal E-Waste Recycling Sites in Cameroun. European Journal of Sustainable Development Research, 2(4), 44. https://doi.org/10.20897/ejosdr/3912

Published: October 4, 2018

\begin{abstract}
This study assessed the levels and human health risk of polychlorinated biphenyls (PCBs) in soils of e-waste recycling sites in Douala, Cameroun. Surface soil samples from these sites were collected and analyzed by Gas Chromatography- Electron Capture Detector to quantify the levels of 30 PCBs (including 10 dioxinlike PCBs). The investigated $30 \mathrm{PCBs}$ were detected in all the soil samples. The mean and standard deviation of the total PCBs in Makea, Ngodi and New Bell recycling sites were 32.1 $\pm 4.48,31.9 \pm 0.10$ and $72.8 \pm 13.5$ $\mathrm{ng} / \mathrm{g}$, respectively. Between $26-46 \%$ of the $\Sigma 30 \mathrm{PCB}$ concentrations were comprised of the dioxin-like PCB congeners. The toxic equivalent (TEQ) values of 10 dioxin-like PCBs were lower than the Canadian soil quality guidelines of dioxin $\left(4 \mathrm{pg}\right.$ TEQ $\left.\mathrm{g}^{-1}\right)$. Human health risk through ingestion, dermal contact, and inhalation was lower than the values of cancer risk $\left(10^{-}\right)$indicating low adverse effects of PCBs in the recycling sites.
\end{abstract}

Keywords: polychlorinated biphenyls, health risk, e-waste, Douala

\section{INTRODUCTION}

Electronic and electrical waste (e-waste) recycling which hitherto is considered a lucrative business has negative impacts on the environment and health of the public, especially in developing nations, such as Cameroun, Ghana, India, and Brazil where environmental regulations are absent or weakly implemented (Garlapati, 2016). E-waste includes end-of-life electronic products such as television sets, computers, printers, toys, mobile phones and photocopy machines etc. E-waste has contributed enormously to the growing problem in the field of waste management in the world (Halluite et al., 2005). Based on the report of the United Nations Environment Programme, UNEP (2005), 20 to 50 million tonnes of e-waste are generated worldwide annually, and the amount is expected to increase by 3 to $5 \%$ per annum (Commission of the European Communities, 2000). Technological advancement has resulted in high demand for latest and highly efficient materials as opposed to old and obsolete ones. In the United States, it was estimated that over 500 million computer became out-dated between 1997 and 2007 (NSC, 1999). It was also reported that $50 \%$ to $80 \%$ of the e-waste collected for recycling in industrialized countries, such as the U.S. was illegally transported to Asian countries, such as China, India, and Pakistan, for recycling and disposal (BAN and SVTC, 2002). However, the recycling industries in these countries are often crude 
and do not have the appropriate facilities to safeguard environmental and human health. In China alone, about 4 million personal computers are discarded per year (UNEP, 2005).

Crude methods such as mechanical shredding of electronic equipment, open burning of plastics and wires, and acid leaching of printed circuit boards have been used for e-waste recycling. These have led to pollution by the release of hazardous chemicals including polychlorinated biphenyls (PCBs), polycyclic aromatic hydrocarbons (PAHs), polybrominated diphenyls ethers (PBDEs), polychlorinated dibenzo-p-dioxins (PCDDs), polychlorinated dibenzofurans (PCDFs) and heavy metals such as $\mathrm{Cr}, \mathrm{Cd}, \mathrm{Cu}$ and $\mathrm{Pb}$ into the air, dust, soil, river water and sediment (Leung et al., 2007; Li et al., 2007; Wong et al., 2007).

Polychlorinated biphenyls (PCBs) are a group of POPs produced as by-products of industrial or thermal processes by the direct chlorination of biphenyls. There are 209 individual congeners of PCBs (Mills et al., 2007; Haddaoui et al., 2016). PCBs have been used in many nations because of their high thermal stability and this has led to environmental pollution (Hornbuckle et al., 2006). As a result of their toxic characteristics, PCBs have either been restricted or banned, but they are still found in the environment, even far from their emission sources (Gandhi et al., 2015). Electronic waste recycling centres have become hot spots for Persistent Organic Pollutants (POPs) and heavy metals (Leung et al., 2007). Increased levels of blood lead in children and PCBs in the serum of e-waste workers, and dioxins in the human milk of mothers indicated serious threat to the health of local people due to uncontrolled e-waste recycling activities (Bi et al., 2007; Chan et al., 2007; Huo et al., 2007).

Majority of the domestic and/or imported e-waste in Cameroon through the scrap dealers reach the informal recyclers which consists of unregulated and unregistered, low-technology units where both adults and children process e-waste through dangerous procedures without safety measures. In this study, The PCBs in surface soil samples from three informal e-waste recycling sites in Douala, Cameroun were investigated with a view to ascertain their levels and health risks.

\section{MATERIALS AND METHODS}

\section{Sampling Sites}

Surface soil samples (0-20 cm depth) were collected between February and June 2017 from three informal ewaste recycling sites that are Ngodi, Makea and New Bell in Douala, Cameroun. At each sampling site, composite samples consisting of 10 sub-samples were collected into pre-cleaned glass bottles. Samples were stored in ice chest and transported into the laboratory for analysis.

\section{Soil Sample Extraction and Clean-up}

$5 \mathrm{~g}$ of soil sample was placed into a beaker and extracted with $20 \mathrm{~mL}$ of acetone $/ \mathrm{n}$-hexane $(1: 1 \mathrm{v} / \mathrm{v})$. The beaker was sonicated for $10 \mathrm{~min}$ in an ultrasonic bath and the extract was transferred to another beaker. The extraction was repeated with $10 \mathrm{~mL}$ of the solvent mixture. The extracts were combined and concentrated to about $1 \mathrm{~mL}$. Thereafter, samples were cleaned-up and fractionated on a multilayered silica gel column containing from bottom: $3 \mathrm{~g}$ of silica gel and $3 \mathrm{~g}$ of anhydrous sodium sulphate. The sample extracts were loaded in the above-mentioned multilayer column and subsequently eluted with $20 \mathrm{~mL}$ of $\mathrm{n}$ hexane. The purified extract was concentrated and then re-constituted in $2 \mathrm{~mL}$ hexane.

\section{Instrumental Analysis}

Soil samples were analyzed for PCBs with a gas chromatograph (GC) (Agilent 7890) equipped with a 5977A mass spectrometer (MS) detector. HP-5MS fused capillary column $(30 \mathrm{~m}, 0.25 \mathrm{~mm}, 0.25 \mu \mathrm{m})$ was used. Helium was the carrier gas at $1.0 \mathrm{~mL} / \mathrm{min}$ under constant-flow mode. The oven temperature started at $100{ }^{\circ} \mathrm{C}$ for $1 \mathrm{~min}$ and increased to $140{ }^{\circ} \mathrm{C}(0 \mathrm{~min}$ hold time $)$ at a rate of $4{ }^{\circ} \mathrm{C} / \mathrm{min}$, then ramped to $180^{\circ} \mathrm{C}(0 \mathrm{~min}$ hold time $)$ at a rate of $20^{\circ} \mathrm{C} / \mathrm{min}$ then to $210^{\circ} \mathrm{C}(0 \mathrm{~min}$ hold time $)$ at a rate of $3{ }^{\circ} \mathrm{C} / \mathrm{min}$ and finally to $290{ }^{\circ} \mathrm{C}(10 \mathrm{~min}$ hold time $)$ at a rate of $8{ }^{\circ} \mathrm{C} / \mathrm{min}$. Splitless injection of $1 \mu \mathrm{L}$ sample was performed with a $3 \mathrm{~min}$ solvent delay time. Injector temperature was $250^{\circ} \mathrm{C}$. Thirty PCB congeners viz., PCB-8, 28, 37, 44, 49, 52, 60, 66, 70, 74, 77, 81, 82, 87, 99 , $101,105,114,118,123,128,138,153,156,157,167,170,179,180$ and 189 were analyzed in Single Ion Monitoring (SIM) mode. Compounds were identified based on their retention time, target and qualifier ions, and were quantified using the external standard calibration procedure.

\section{Quality Assurance/Quality Control (QA/QC)}

QA/QC was performed using procedural blanks and multi-level calibration curves $\left(\mathrm{r}^{2}\right)$ ranged from 0.9970.999. The limit of detection was between 0.001 and $0.0014 \mathrm{ng} / \mathrm{g}$ for PCBs. The concentrations of the targeted compounds in the procedural blanks were below the quantification limit of the instrument. In this study, all the data were expressed on a dry-weight basis (ng/g dry weight). 


\section{Statistical Analysis}

Statistical analyses were performed using statistical software package SPSS version 16.0. Test of significance for variability in the distribution of $\mathrm{PCB}$ congeners among different sites were carried out using one way Analysis of Variance (ANOVA).

\section{Toxic Equivalency (TEQ) and Health Risk Assessment}

The Toxic Equivalency (TEQ) values of PCBs were calculated by multiplying the detected concentration with the corresponding Toxic Equivalent Factors (TEFs) provided by the World Health Organization (WHO) (Van den Berg et al., 2006).

$\mathrm{TEQ}=\left(\mathrm{C}_{\mathrm{i}} \times \mathrm{TEF}_{\mathrm{i}}\right)$

where $\mathrm{C}_{\mathrm{i}}$ is the individual dioxin-like PCBs concentration in the soil sample, and

$\mathrm{TEF}_{\mathrm{i}}$ is the TEQ factor assigned to individual dioxin-like PCBs.

In this study, the following equations were applied to assess health risks of PCBs (USEPA, 1997; 2009):

CRingest $=\left(\mathrm{C} \times \mathrm{IngR} \times \mathrm{EF} \times \mathrm{ED} \times \mathrm{CF} \times \mathrm{SF}_{\text {oral }}\right) /(\mathrm{BW} \times \mathrm{AT})$

$\mathrm{CRdermal}=\left(\mathrm{C} \times \mathrm{SA} \times \mathrm{AF} \times \mathrm{ABS} \times \mathrm{EF} \times \mathrm{ED} \times \mathrm{CF} \times \mathrm{SF}_{\text {oral }} \times \mathrm{GIABS}\right) /(\mathrm{BW} \times \mathrm{AT})$

CRinhal $=(\mathrm{C} \times \mathrm{InhR} \times$ AFInh $\times \mathrm{EF} \times \mathrm{ED} \times \mathrm{IUR}) /(\mathrm{PEF} \times \mathrm{BW} \times \mathrm{AT})$

where CRingest: the cancer risk via accidental soil ingestion, CRdermal: the cancer risk (soil dermal contact); CRinhal: the cancer risk (soil inhalation), C: concentration of soil PCBs ( $\left.\mathrm{mg} \mathrm{kg}^{-1}\right)$, IngR: the rate of ingestion (100 $\mathrm{mg}$ soil/day), CF: conversion factor $\left(10^{-6} \mathrm{~kg} / \mathrm{mg}\right.$ ), EF: exposure frequency (350 days/year) ED: exposure duration (70 years), BW: body weight (70 kg), AT: averaging time (days); calculated as $70 \times 365=25,550$, SA: skin surface area available for contact $\left(3300 \mathrm{~m}^{2}\right) \mathrm{AF}$ : adherence factor from soil to skin $\left(0.2 \mathrm{mg} / \mathrm{cm}^{2}\right), \mathrm{SF}_{\text {oral }}=$ the factor of oral slope $\left.\left(2 \mathrm{mg} \mathrm{kg}^{-1} \mathrm{~d}^{-1}\right)^{-1}\right)$, PEF: emission factor of particle $\left(1.36 \times 109 \mathrm{~m}^{3} \mathrm{~kg}^{-1}\right)$, InhR: inhalation rate $\left(15.8 \mathrm{~m}^{3} /\right.$ day $)$, AFInh: the lungs absorption factor (1.0), ABS: absorption factor (0.10), IUR: the risk unit for inhalation (5.7E-01 $\left.\left(\mathrm{mg} \mathrm{m}^{3}\right)^{-1}\right)$, GIABS: the fraction of pollutant taken by gastrointestinal tract (1.0).

\section{RESULTS AND DISCUSSION}

\section{PCBs Concentrations in Soil Samples}

The mean concentrations of the total PCBs in surface soils are shown in Table 1. The mean and standard deviation of $\Sigma 30$ PCB in Makea, Ngodi and New Bell recycling sites were 32.1 $\pm 4.5,31.9 \pm 0.1$ and $72.8 \pm 14$ respectively. The corresponding values for $\Sigma 10 \mathrm{dl}-\mathrm{PCB}$ were $14.7 \pm 2.1,13.9 \pm 0.9$ and $19.0 \pm 8.2 \mathrm{ng} / \mathrm{g}$ respectively. Dioxin like PCBs accounted for $26-46 \%$ of the total PCB concentration in the soil samples. New Bell recycling site had the highest concentration of the total PCBs and dioxin-like PCBs which indicated higher contamination when compared with other recycling sites in Douala. The total PCB levels in the E-waste recycling sites in Douala were however below the Dutch action value, the Australian and New Zealand ecological investigation level of 1000 $\mu \mathrm{g} / \mathrm{kg}$, as well as the Canadian soil guideline for residential areas of $1300 \mu \mathrm{g} / \mathrm{kg}$ (Canadian Environmental Quality Guidelines, 2003). This study showed lower PCB contamination levels than previously reported for contaminated soils in China (Zhao et al., 2008; Shen et al., 2009) and slightly higher than the reported concentration from South Africa (Nieuwoudt et al., 2009). The $\Sigma 10 \mathrm{dl}-\mathrm{PCB}$ in the present study were lower than what was observed in the e-waste metal recovery site in India (Chakraborty et al., 2016). 
Table 1. The mean and standard deviation of PCBs $(\mathrm{ng} / \mathrm{g})$ in soils from recycling sites in Douala, Cameroun

\begin{tabular}{|c|c|c|c|}
\hline Pollutants & Makea & Ngodi & New Bell \\
\hline PCB 8 & ND & ND & $0.08 \pm 0.1$ \\
\hline Total Di-PCBs & ND & ND & $0.08 \pm 0.1$ \\
\hline PCB 28 & $0.4 \pm 0.0$ & $0.44 \pm 0.1$ & $1.06 \pm 0.8$ \\
\hline PCB 37 & $0.17 \pm 0.1$ & $0.25 \pm 0.2$ & $2.59 \pm 2.0$ \\
\hline Total tri-PCBs & $0.57 \pm 0.1$ & $0.69 \pm 0.2$ & $3.65 \pm 2.8$ \\
\hline PCB 44 & ND & $0.01 \pm 0.01$ & $2.13 \pm 2.7$ \\
\hline PCB 49 & $0.18 \pm 0.1$ & $0.27 \pm 0.2$ & $13.95 \pm 11$ \\
\hline PCB 52 & $0.45 \pm 0.3$ & $0.43 \pm 0.04$ & $7.44 \pm 5.2$ \\
\hline PCB 60 & $0.67 \pm 0.02$ & $0.76 \pm 0.1$ & $4.44 \pm 4.2$ \\
\hline PCB 66 & $0.59 \pm 0.03$ & $0.63 \pm 0.1$ & $1.55 \pm 0.3$ \\
\hline PCB 70 & $1.58 \pm 0.3$ & $0.78 \pm 0.1$ & $5.64 \pm 6.2$ \\
\hline$\overline{\text { PCB } 74}$ & $0.83 \pm 0.01$ & $0.56 \pm 0.5$ & $2.21 \pm 1.5$ \\
\hline PCB 77 & $1.45 \pm 0.3$ & $0.93 \pm 0.1$ & $3.48 \pm 2.6$ \\
\hline PCB 81 & $1.87 \pm 0.3$ & $1.93 \pm 0.1$ & $1.82 \pm 0.2$ \\
\hline Total tetra-PCBs & $7.59 \pm 1.4$ & $6.29 \pm 1.3$ & $42.6 \pm 34$ \\
\hline PCB 82 & $0.25 \pm 0.03$ & $0.64 \pm 0.3$ & $0.47 \pm 0.3$ \\
\hline PCB 87 & $0.72 \pm 0.01$ & $0.86 \pm 0.2$ & $0.71 \pm 0.01$ \\
\hline PCB 99 & $0.85 \pm 0.04$ & $0.93 \pm 0.1$ & $0.89 \pm 0.1$ \\
\hline PCB 101 & $1.27 \pm 0.3$ & $1.21 \pm 0.03$ & $1.09 \pm 0.2$ \\
\hline PCB 105 & $1.14 \pm 0.02$ & $1.15 \pm 0.01$ & $1.33 \pm 0.1$ \\
\hline PCB 114 & $\mathrm{ND}$ & $\mathrm{ND}$ & ND \\
\hline PCB 118 & $2.18 \pm 0.5$ & $1.53 \pm 0.5$ & $4.60 \pm 4.9$ \\
\hline$\overline{\mathrm{PCB}} 123$ & $1.26 \pm 0.1$ & $1.29 \pm 0.1$ & $1.22 \pm 0.04$ \\
\hline Total penta-PCBs & $7.66 \pm 1.0$ & $7.58 \pm 1.1$ & $10.3 \pm 5.6$ \\
\hline PCB 128 & $3.57 \pm 0.6$ & $3.83 \pm 0.3$ & $3.28 \pm 0.4$ \\
\hline PCB 138 & $1.66 \pm 0.3$ & $1.70 \pm 0.04$ & $1.53 \pm 0.2$ \\
\hline PCB 153 & ND & $0.57 \pm 0.8$ & $0.71 \pm 1.0$ \\
\hline PCB 156 & $1.26 \pm 0.2$ & $1.33 \pm 0.2$ & $1.16 \pm 0.1$ \\
\hline PCB 157 & $1.45 \pm 0.1$ & $1.47 \pm 0.01$ & $1.43 \pm 0.01$ \\
\hline PCB 167 & $2.24 \pm 0.5$ & $2.38 \pm 0.3$ & $2.06 \pm 0.3$ \\
\hline Total hexa-PCBs & $10.2 \pm 1.7$ & $11.3 \pm 1.6$ & $10.2 \pm 2.0$ \\
\hline PCB 170 & $0.98 \pm 0.04$ & $0.95 \pm 0.01$ & $0.96 \pm 0.1$ \\
\hline PCB 179 & $1.43 \pm 0.2$ & $1.46 \pm 0.01$ & $1.36 \pm 0.1$ \\
\hline PCB 180 & $1.83 \pm 0.2$ & $1.85 \pm 0.1$ & $1.76 \pm 0.2$ \\
\hline PCB 189 & $1.92 \pm 0.1$ & $1.88 \pm 0.01$ & $1.91 \pm 0.1$ \\
\hline Total hepta-PCBs & $6.16 \pm 0.5$ & $6.13 \pm 0.1$ & $5.98 \pm 0.4$ \\
\hline$\Sigma 30$ PCBs & $32.1 \pm 4.5$ & $31.9 \pm 0.1$ & $72.8 \pm 14$ \\
\hline$\Sigma 10$ DL-PCBs & $14.7 \pm 2.1$ & $13.9 \pm 0.9$ & $19.0 \pm 8.2$ \\
\hline TEQ (pg TEQ g $\left.{ }^{-1}\right)$ & $1.05 \pm 0.2$ & $1.00 \pm 0.1$ & $1.30 \pm 0.5$ \\
\hline
\end{tabular}

As described in Figure 1a-c, the lower chlorinated congeners such as tri-, tetra-, and penta-PCB were the abundant pollutants in all the sites, accounting for almost $50 \%$ of the total PCBs. The tetra-PCB was the most prevalent homolog in New Bell and hexa-PCB in Makea and Ngodi, while dl-PCB was the least prevalent in all the sites. The concentrations in Table 1 showed that the mean values of di-, tri-, tetra-, penta-, hexa- and hepta-PCB in Makea, Ngodi, and New Bell were ND, 0.57 $\pm 0.1,7.59 \pm 1.4,7.66 \pm 1.0,10.2 \pm 1.7$ and $6.16 \pm 0.5$; ND, $0.69 \pm 0.2$, $6.29 \pm 1.3,7.58 \pm 1.1,11.3 \pm 1.6$ and $6.13 \pm 0.1$; and $0.08 \pm 0.1,3.65 \pm 2.8,42.6 \pm 34,10.3 \pm 5.6,10.2 \pm 2.0$ and $5.98 \pm 0.4$ $\mathrm{ng} / \mathrm{g}$, respectively. 


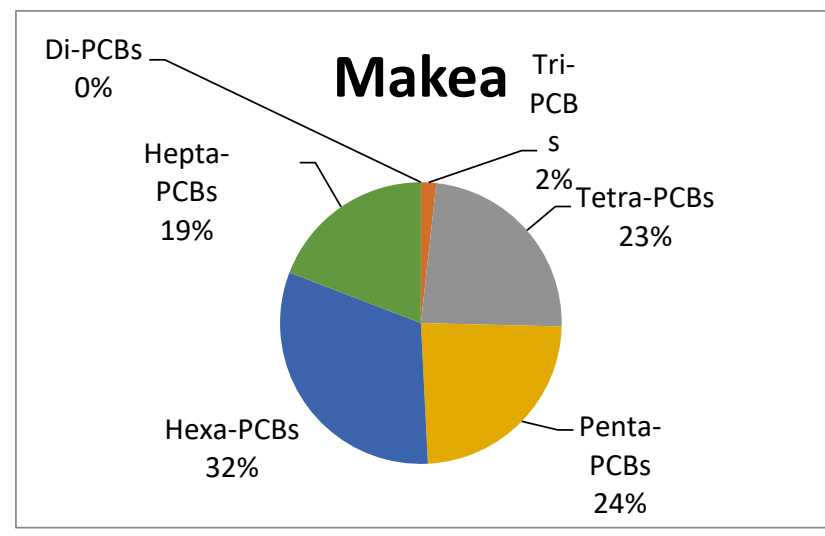

(a)

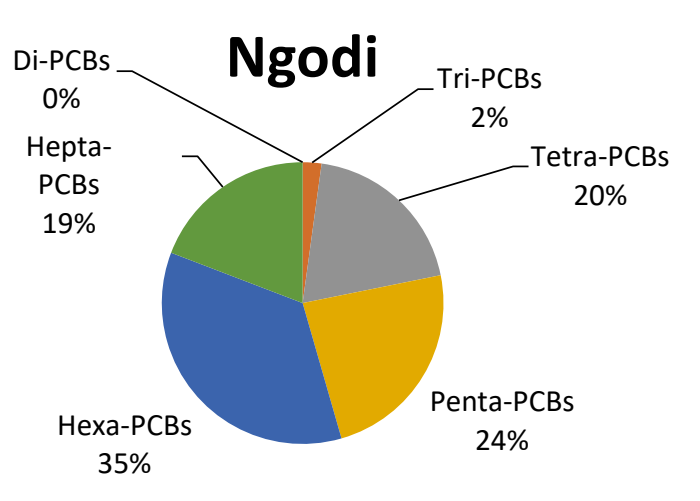

(b)

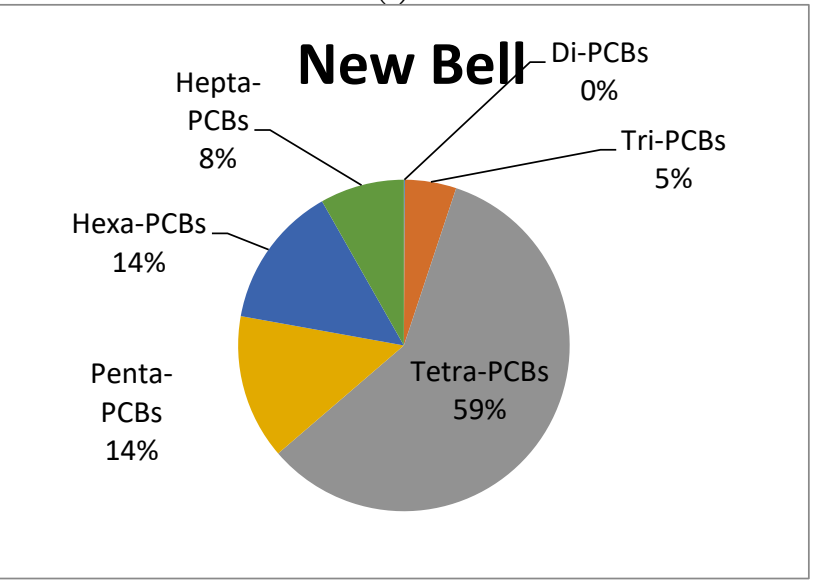

(c)

Figure 1. The percentage distribution of the PCB congeners in soil samples collected from e-waste recycling sites in Douala, Cameroun

In Cameroun, open burning of cable wires, circuit boards and atmospheric transport could be the sources for PCB pollution in the area, and no quality standard has been set for PCBs in soils. The composition of PCBs in this study was compared with the study conducted by Tang et al., 2010 who reported that low-chlorinated PCB homologs accounted for $69-87 \%$ of the total PCBs in soil samples collected from an e-waste recycling site in Wenlin, China (Tang et al., 2010a). Di-, tri-, tetra-, and penta-PCBs were the prevalent congeners in soil sample around the recycling area of Taizhou, China (Tang et al., 2010b). Bi et al. (2002) reported that tetra- and pentaPCBs were predominant in Taizhou in 1993, 1997 and 1999. Similar results were reported by Shen et al. (2009). The high concentration of low-chlorinated PCBs implies that the sites had been used for the disposal of dielectric medium in transformers and capacitors containing Arochlor 1242 and 1254 (Tang et al., 2010b). Several researchers have reported abundance of highly chlorinated PCBs such as hexa-PCBs and hepta-PCBs in urban and industrial soils (Meijer et al., 2002; Nakata et al., 2005; Syed et al., 2013). Higher chlorinated PCBs are less volatile, strongly retained to fine soil particles and not easily biodegraded (Ge et al., 2013). High affinity to soil organic matter and hydrophobicity contribute to high abundance of PCBs (Qiang et al., 2012).

\section{Risk Assessment}

Risk associated with PCB concentrations in the recycling sites was done using TEQs. New Bell recycling site showed the highest range of TEQs $(1.30 \pm 0.49 \mathrm{pg}$ TEQ g-1) followed by Makea (1.05 $\pm 0.15 \mathrm{pg}$ TEQ g-1) and Ngodi $(1.00 \pm 0.05 \mathrm{pg}$ TEQ g-1). The risk of PCBs reported in this study was lower than what was reported in India (Chakraborty et al., 2016). The obtained TEQ values of dioxin-like PCBs in the present study did not exceed the Canadian soil quality guidelines of dioxin (4 pg TEQ g-1). TEQ values of soil in the study area were lower than what was reported in Punjab Province, Pakistan (Syed et al., 2013) and higher than those obtained in the study conducted by Ma et al. (2009) in top soils of Harbin, China.

The risk for human by soil particles in the present study was assessed through calculation of cancer risk caused by ingestion, dermal contact, or inhalation. The results clearly showed that the health risk effects of PCBs on human are low, as indicated by the values of cancer risk ranging from $2.9 \times 10^{-12}$ to $1.99 \times 10^{7}$ for all sites investigated (Table 2). 
Table 2. Cancer risks for human by ingestion, dermal contact, and inhalation

\begin{tabular}{llll}
\hline Cancer Risk & Makea & Ngodi & New Bell \\
\hline Ingestion & $8.7945 \mathrm{E}-08$ & $8.4932 \mathrm{E}-08$ & $1.9945 \mathrm{E}-07$ \\
\hline Dermal & $5.8044 \mathrm{E}-08$ & $5.6055 \mathrm{E}-08$ & $1.3164 \mathrm{E}-07$ \\
\hline Inhalation & $2.9119 \mathrm{E}-12$ & $2.8121 \mathrm{E}-12$ & $6.6039 \mathrm{E}-12$
\end{tabular}

\section{CONCLUSION}

The soils from the abandoned e-waste recycling sites in Douala, Cameroun were contaminated with PCBs at low levels and derived human health risk of PCBs was lower than those reported in other industrial sites worldwide. The TEQ values of dioxin-like PCBs in the present study were lower than the Canadian soil quality guidelines of dioxin (4 pg TEQ g-1). The use of primitive and unsafe methods to recycle e-waste can lead to exposure to a variety of toxic substances to human health. These findings recommended that polices to control activities in ewaste recycling areas must be developed and enforced.

\section{ACKNOWLEDGEMENTS}

This work was supported by the African Union through a Doctoral study in Environmental Management by the first author at the Pan African University, Life and Earth Sciences Institute, and by UNESCO through the ANESI exchange program. The authors acknowledge the Department of Chemistry, University of Ibadan, Nigeria for the continuous support throughout the study.

\section{REFERENCES}

BAN and SVTC. (2002). Exporting harm: the high-tech trashing of Asia. The Basel Action Network (BAN) and Silicon Valley Toxics Coalition (SVTC). Available at: http://www.svtc.org/cleancc/pubs/technotrash.pdf

Bi, X. H., Thomas, G. O., Jones, K. C., Qu, W., Sheng, G. and Martin, F. L. (2007). Exposure of electronics dismantling workers to polybrominated diphenyl ethers, polychlorinated biphenyls and organochlorine pesticides in south China. Environ Sci Technol, 41, 5647-5653. https://doi.org/10.1021/es070346a

Bi, X., Chu, S., Meng, Q. and Xu, X. (2002). Movement and retention of polychlorinated biphenyls in a paddy field of WenTai area in China. Agric. Ecosyst. Environ., 89, 241-252. https://doi.org/10.1016/S0167-8809(01)002109

Canadian Environmental Quality Guidelines. (2003). Summary Table. Available at: www.ec.gc.ca/ceqgrcqe/English/ceqg/default.cfm

Chakraborty, P., Zhang, G., Li, J., Selvaraj, S., Breivik, K. and Jones, K. C. (2016). Soil concentrations, occurrence, sources and estimation of air-soil exchange of polychlorinated biphenyls in Indian cities. Sci. Total Environ., 562, 928-934. https:// doi.org/10.1016/j.scitotenv.2016.03.009

Chan, J. K. Y., Xing, G. H., Xu, Y., Liang, Y., Chen, L. X., Wu, S. C., Leung, C. K. M. and Wong, M. H. (2007). Body loadings and health risk assessment of polychlorinated dibenzo-p-dioxins and dibenzofurans at an intensive electronic-waste recycling site in China. Environ. Sci. Technol, 41, 7668-74. https://doi.org/10.1021/es071492j

Commission of the European Communities. (2000). Proposal for a directive of the European parliament and of the council onwaste electrical and electronic equipment/Proposal for a directive of the European parliament and of the council on the restriction of the use of certain hazardous substances in electrical and electronic equipment. Available at: http://www.eeb.org/activities/waste/WEEE\%20and\%20ROS\%20ENfinal.pdf

Gandhi, N., Bhavsar, S. P., Reiner, E. J., Chen, T., Morse, D., Arhonditsis, G. B. and Drouillard, K. G. (2015). Evaluation and interconversion of various indicator PCB schemes for PCB and dioxin-like PCB toxic equivalent levels in fish. Environ. Sci. Technol., 49. 123-31. https://doi.org/10.1021/es503427r

Garlapati, V. K. (2016). E-waste in India and developed countries: Management, recycling, business and biotechnological initiatives. Renewable and Sustainable Energy Reviews, 54, 874-881. https://doi.org/10.1016/j.rser.2015.10.106

Ge, J., Woodward, L. A., Li, Q. X. and Wang, J. (2013). Distribution, sources and risk assessment of polychlorinated biphenyls in soils from the Midway Atoll, North Pacific Ocean. PLoS ONE, 8, 715-721. https://doi.org/10.1371/journal.pone.0071521 
Haddaoui, I., Mahjoub, O., Mahjoub, B., Boujelben, A. and Bella, G. D. (2016). Occurrence and distribution of PAHs, PCBs and chlorinated pesticides in Tunisian soil irrigated with treated wastewater. Chemosphere, 146, 195205. https://doi.org/10.1016/j.chemosphere.2015.12.007

Halluite, J., Linton, J. D., Yeomans, J. and Yoogalingam, R. (2005). The challenge of hazardous waste management in a sustainable environment: insights from electronic recovery laws. Corp Soc Responsib Environ Manage, 12, 31 7. https://doi.org/10.1002/csr.75

Hornbuckle, K. C., Carlson, D. L., Swackhamer, D. L., Baker, J. E. and Eisenreich, S. J. (2006). Polychlorinated biphenyls in the Great Lakes. In Persistent Organic Pollutants in the Great Lakes, ed. R. A. Hites (Verlag Berlin Heidelberg: Springer), 5 (Part N), 13-70. https:/ / doi.org/10.1007/698_5_039

Huo, X., Peng, L., Xu, X., Zheng, L., Qiu, B. and Qi, Z. (2007). Elevated blood lead levels of children in Guiyu, an electronic waste recycling town in China. Environ Health Perspec., 115, 1113-1117. https://doi.org/10.1289/ehp.9697

Leung, A. O. W., Luksemburg, W. J., Wong, A. S. and Wong, M. H. (2007). Spatial distribution of polybrominated diphenyl ethers and polychlorinated dibenzo-p-dioxins and dibenzofurans in soil and combusted residue at Guiyu, an electronic waste recycling site in Southeast China. Environ Sci Technol, 41, 2730-7. https://doi.org/10.1021/es0625935

Li, H., Yu, L., Sheng, G., Fu, J. and Peng, P. (2007). Severe PCDD/F and PBDD/F pollution in air around an electronic waste dismantling area in China. Environ Sci Technol, 41, 5641-6. https://doi.org/10.1021/es0702925

Ma, W., Li, Y. F., Sun, D. Z. and Qi, H. (2009). Polycyclic aromatic hydrocarbons and polychlorinated biphenyls in top soils of Harbin, China. Arch. Environ. Contam. Toxicol., 57, 670-8. https://doi.org/10.1007/s00244-0099314-y

Meijer, S. N., Steinnes, E., Ockenden, W. A. and Jones, K. C. (2002). The influence of environmental variables on the spatial distribution of pcbs in Norwegian and uk soils: Implications for global cycling. Environ. Sci. Tecbnol., 36, 2146-53. https://doi.org/10.1021/es010322i

Mills, S. A., Thal, D. I. and Barney, J. (2007). A summary of the 209 PCB congener nomenclature. Chemosphere, 68, 1603-12. https:// doi.org/10.1016/j.chemosphere.2007.03.052

Nakata, H., Hirakawa, Y. and Kawazoe, M. (2005). Concentrations and compositions of organochlorine contaminants in sediments, soils, crustaceans, fishes and birds collected from Lake Tai, Hangzhou Bay and Shanghai City region, China. Environ. Pollut., 13, 415-29. https://doi.org/10.1016/j.envpol.2004.07.003

National Safety Council. (1999). Electronic product recovery and recycling baseline report. NSD, Washington, DC.

Nieuwoudt, C., Quinn, L. P., Pieters, R., Jordaan, I., Visser, M., Kylin, H., Borgen, A. R., Giesy, J. P. and Bouwman, H. (2009). Dioxin-like chemicals in soil and sediment from residential and industrial areas in central South Africa. Chemosphere, 76, 774-783. https://doi.org/10.1016/j.chemosphere.2009.04.064

Qiao, M., Wang, C., Huang, S., Wang, D., Wang, Z. (2006). Composition, sources and potential toxicological significance of PAHs in the surface sediments of the Meiliang Bay, Taihu Lake, China. Environ. Int., 32, $28-33$. https:// doi.org/10.1016/j.envint.2005.04.005

Qiang, W., YeHong, S., Xin, H. J., Wei, Y. Z., Kun, F. X. and An, D. Y. (2012). Determination of dioxin-like polychlorinated biphenyls in soil and moss from Fildes Peninsula, Antarctica. Cbin. Sci. Bull., 57, 992-6. https://doi.org/10.1007/s11434-011-4969-y

Shen, C., Chen, Y., Huang, S., Wang, Z., Yu, C., Qiao, M., Xu, Y., Setty, K., Zhang, J., Zhu, Y. and Lin, Q. (2009). Dioxin-like compounds in agricultural soils near e-waste recycling sites from Taizhou area, China: chemical and bioanalytical characterization. Environ. Int., 35, 50-55. https://doi.org/10.1016/j.envint.2008.07.005

Syed, J. H., Malik, R. N., Li, J., Zhang, G. and Jones, K. C. (2013). Level, distribution and air-soil exchange fluxes of polychlorinated biphenyls (PCBs) in the environment of Punjab Province, Pakistan. Ecotoxicol. Environ. Saf., 97, 89-195. https://doi.org/10.1016/j.ecoenv.2013.06.005

Tang, X. J., Shen, C. F., Shi, D. Z., Cheema, S. A., Khan, M. I., Zhang, C. K. and Chen, Y. X. (2010a). Heavy metal and persistent organic compound contamination in soil from Wenling: an emerging e-waste recycling city in Taizhou area, China. J. Hazard Mater., 173, 653-660. https://doi.org/10.1016/j.jhazmat.2009.08.134

Tang, X. J., Shen, C. F., Chen, L., Xiao, X., Wu, J. Y., Khan, M. I., Dou, C. M. and Chen, Y. X. (2010b). Inorganic and organic pollution in agricultural soil from an emerging e-waste recycling town in Taizhou area, China. J. Soils Sediments, 10, 895-906. https://doi.org/10.1007/s11368-010-0252-0

UNEP. (2005). E-waste: the hidden side of IT equipment's manufacturing and use. Early Warnings on Emerging Environmental Threats No.5. United Nations Environment Programme.

USEPA. (U.S. Environmental Protection Agency). (1997). Exposure Factors Handbook. EPA/600/P-95/002 F (Washington, DC: Environmental Protection Agency).

USEPA. (U.S. Environmental Protection Agency). (2009). Risk Assessment Guidance for Superfund. Vol. I: human health evaluation manual (F, supplemental guidance for inhalation risk assessment) EPA/540/R/070/002 (W ashington, DC: Environmental Protection Agency). 
Van den Berg, M., Birnbaum, L. S., Denison, M., De Vito, M., Farland, W., Feeley, M., Fiedler, H., Hakansson, H., Hanberg, A. and Haws, L. (2006). The 2005 World Health Organization reevaluation of human and mammalian toxic equivalency factors for dioxins and dioxin-like compounds. Toxicol. Sci., 93, $223-241$. https://doi.org/10.1093/toxsci/kfl055

Wong, C. S. C., Duzgoren-Aydin, N. S., Aydin, A. and Wong, M. H. (2007). Evidence of excessive releases of metals from primitive e-waste processing in Guiyu, China. Environ Pollut., 148, 62-72. https://doi.org/10.1016/j.envpol.2006.11.006

Zhao, G., Wang, Z., Dong, M. H., Rao, K., Luo, J., Wang, D., Zha, J., Huang, S., Xu, Y. and Ma, M. (2008). PBBs, PBDEs and PCBs levels in hair of residents around e-waste disassembly sites in Zhejiang Province, China and their potential sources. Sci. Total Environ., 397, 46-57. https://doi.org/10.1016/j.scitotenv.2008.03.010 